\title{
Study of Sensory Marketing Strategies in Retailing Business
}

\author{
Swaroop Simha* \\ Professor of Marketing \& Coordinator, JSS - Centre for Management Studies \\ JSS Science and Technology University, JSS Technical Institutions Campus, SJCE \\ Mysore \\ *simhaswaroopa@gmail.com
}

\begin{abstract}
Sensory marketing" has been defined as "marketing that engages the consumers' senses and affects their perception, judgment and behavior." (Aradhana Krishna, in her book Customer Sense- How the five senses influence the buying behavior, Kindle edition [2]) From a managerial perspective, sensory marketing can be used to create subconscious triggers that characterize consumer perceptions of abstract notions of the product (e.g., its sophistication or quality). Every day the consumer is exposed to a gamut of sensory triggers which works subconsciously in stimulating and influencing consumers buying behavior. Also, these sensory triggers may result in consumers' self-generation of (desirable) brand attributes, rather than those verbally provided by the advertiser. The understanding of these sensory triggers implies an understanding of sensation and perception as it applies to consumer behavior-this is the research perspective of sensory marketing.
\end{abstract}

Keywords—sensory marketing, senses, perceptions, buying behavior, retail scape, strategies, brand management

\section{INTRODUCTION}

A. Sensuality in Marketing: Awakening the Five Senses in the Marketing World

Miriam Webster defines Sensuality as providing pleasure through gratification of the senses. It also implies gratification of the senses for the sake of aesthetic pleasure. The modern day consumer has a very discerning eye with regards the products and services he avails. He is now seeking and willing to pay for not just the shopping but for the experience of shopping. Marketers need to wake up pay lot more attention to do marketing that engages the consumers' senses and affects their behaviors. While looking at the products sensory aspects, i.e., the touch, taste, smell, sound, and look of the products, can affect consumers emotions, memories, perceptions, preferences, choices, and finally consumption of these products. It is seen that by creating new sensations or merely emphasizing or bringing attention to existing sensations, it can increase a product's or service's appeal $[1,2]$.

Purpose of the study: is to explore and study at the retail level, the effectiveness of mental simulation and mental imagery evoked by visuals enhancing promotional effectiveness, Multi-sensory stimulation in ad copy enhancing actual taste perceptions. Touch, actual or imagined, or increasing consumer product evaluations. Smell enhancing memory for product descriptions and thereby affecting product evaluations, and finally music in advertising affecting attention and increases promotional persuasiveness,

Objective: The study discusses the role of sensory marketing in driving promotional communication and retail scope effectiveness for different category of products and service brands at the retail outlets.

\section{B. Sensory Marketing - The model}

Sensory marketing puts human brain with its five senses, at the center of marketing. It is in the brain of an individual of an individual that a brand registers and an image is created in terms of mental conceptions and imaginations. This image is a result of experiences an individual has of a firm or a brand. Each individual has a subjective experience that we call "experience logic". This logic is individual and personal. It is the result of how the individual's five senses perceive and interpret an experience, either singly or together [1,3] (show in figure 1 and 2).

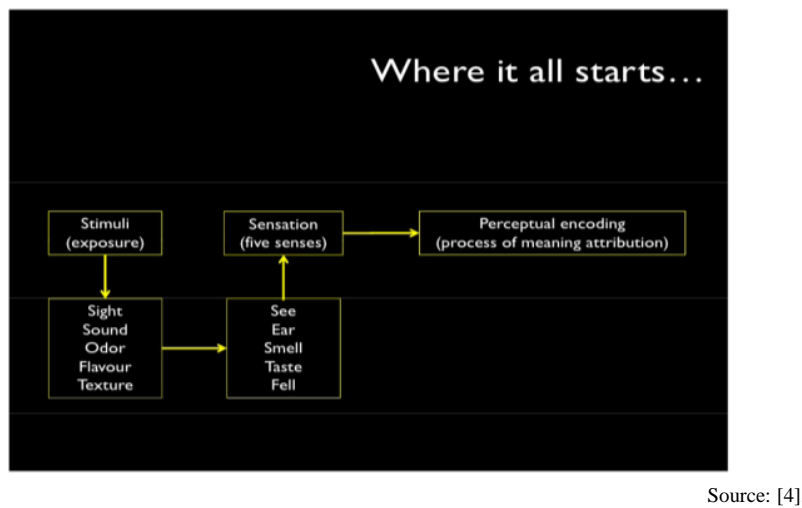

Fig. 1. Sensory marketing.

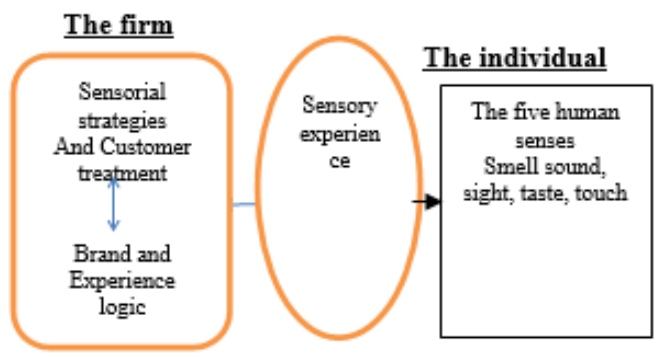

Fig. 2. Sensory marketing $[1,5]$. 


\section{Sensory Marketing and Retailing}

In Sensory marketing in retailing, the retailer is expected to understand how to treat customers in a more intimate and personal way than was achieved with mass and relationship marketing before [4]. And the road to success goes to a great extent via emotion. When many customers turn away from appreciating only functional product attributes and features instead want to see the product as an experience [6].

The retail scape should be so designed to create:

- Mental simulation and mental imagery as evoked by ad visuals enhance promotional effectiveness and Visual merchandising.

- Multi-sensory stimulation in visual copy enhances actual taste perceptions.

- Touch, actual or imagined, increases consumer product evaluations.

- Smell enhances memory for product descriptions and affects product evaluations.

- Music in advertising affects attention and increases promotional persuasiveness $[7,8,9]$.

\section{DESIGN/METHODOLOGY/APPROACH}

The study was conducted to compare and contrast two similar line retail businesses having similar types or products and services and their attempt at influencing consumers perceptions in their buying behavior based on their sensory marketing strategies. Also to understand the importance of designing retail scape in creating customer experience using the above mentioned aspects $[7,8]$.

The study involved primarily observation, followed by interviewing customers outside the stores, (Qualitative method) and based on the observation of the customers, behavior and actions within the store; Researcher used a moderator's guide and asked simple questions related to sensory marketing effort by the retailer, were checked with the customers. The study was conducted in the city of Mysore in India (Southern part of India, in the state of Karnataka) [10].

\section{A. Approach and Summary}

This paper discusses the role of sensory marketing in driving promotional effectiveness. First focusing on vision, where the effect of mental simulation and mental imagery evoked by visuals/color scheme used and graphic prints used, lighting effects in retail outlets for promotional effectiveness. (Specifically in Visual Merchandising)

Nike and Puma, are two retail stores which were compared (these stores were in the same mall and venue). Secondly, the effect of multi-sensory stimulation on taste perceptions was taken up in those retail outlets which is predominantly taste based, Two Ice cream retail outlets (different venues) namely Corner House and Baskin Robins were compared, and this was followed by two fast food restaurants namely KFC and MacDonald's (found in the same Mall) were compared. Finally, to elaborate on the role of actual and imagined touch in shaping consumer evaluations and behaviors, the retail stores of Life style and Pantaloons (located in the same mall) were chosen for comparison and confirmation, for sensory marketing strategies applied in these stores and their effectiveness in attracting more customers. Finally, effort was made to understand what drives the consumer inside the store and how consumers' memory acts as a key driver of promotional recall and responses to the role of visuals, tactile, taste, auditory and olfaction senses in all the retail stores.

The following summary presents the review and effectiveness of the 8 retail outlets in Mysore, based on observation and customer's response and feedback collected with regards to sensory marketing strategies applied by these retailers to influence consumers buying behavior.

\section{1) Sports apparel and equipment retailing:}

- On comparing PUMA and Nike stores, Observation had them on par on most features, attributes and characteristics, however, the survey questions yielded results, which showed that Nike store was greatly appreciated for its sensory marketing effort and had higher impact on its customers visiting the store. The visuals and graphic prints on display within the store were found very appealing to the visitors

- Nike stores had more customers visiting the store than Puma. Also Nike scored higher in the overall "highly satisfied" score rating by consumers.

- Which is better at sensory marketing (50 respondents were questioned), the respondents show in table 1 .

\section{TABLE I. RESPONDENTS}

\begin{tabular}{|l|l|}
\hline NIKE & 29 \\
\hline PUMA & 20 \\
\hline
\end{tabular}

- Which sensory organ was in play at Nike showroom? The sensory organ in Nike showroom in table 2 and the category PUMA and NIKE in table 3.

TABLE II. THE SENSORY ORGAN IN NIKE SHOWROOM

\begin{tabular}{|l|l|}
\hline Taste & 0 \\
\hline Sight/ambience & 27 \\
\hline Smell & 4 \\
\hline Music & 5 \\
\hline Touch & 20 \\
\hline
\end{tabular}

TABLE III. CATEGORY PUMA AND NIKE

\begin{tabular}{|c|c|}
\hline $\begin{array}{c}\text { PUMA } \\
\text { Only franchise outlet in the } \\
\text { city }\end{array}$ & $\begin{array}{c}\text { NIKE } \\
\text { Has both factory outlet and } \\
\text { franchise outlet in the city Mall }\end{array}$ \\
\hline $\begin{array}{l}\text { Categories: accessories, } \\
\text { sports apparels, footwear, } \\
\text { perfumes visuals were } \\
\text { displayed }\end{array}$ & $\begin{array}{l}\text { Categories: sports apparels, } \\
\text { accessories, footwear visuals and } \\
\text { color graphics on display }\end{array}$ \\
\hline $\begin{array}{l}\text { Congested as it is small store } \\
\text { Air quality was not cool } \\
\text { Music was soft } \\
\text { Trial could have been better }\end{array}$ & $\begin{array}{l}\text { Store is big, not congested } \\
\text { Air quality was good } \\
\text { Music was instrumental } \\
\text { Trial was comfortable }\end{array}$ \\
\hline Targets younger crowd & Targets sports people \\
\hline
\end{tabular}


2) Food retailing: Taste is at the top of importance of ranking [11,12].

a) Comparison of ice cream retail outlets:

- Corner House and Baskin Robins, two popular Ice cream retail outlets were compared, Corner house despite not high on many accounts still did high on taste and had higher customer loyalty and effectiveness. Observation and survey yielded these results. The result comparison of ice cream retail outlets in table 4.

TABLE IV. COMPARISON OF ICE CREAM RETAIL OUTLETS

\begin{tabular}{|l|l|}
\hline \multicolumn{1}{|c|}{ CORNER HOUSE } & \multicolumn{1}{c|}{ BASKIN ROBBINS } \\
\hline Seating area is big & Seating area is small \\
\hline $\begin{array}{l}\text { They had long list of choices in the } \\
\text { menu }\end{array}$ & $\begin{array}{l}\text { The choices on menu were } \\
\text { fewer }\end{array}$ \\
\hline $\begin{array}{l}\text { The menu Board was displayed in the } \\
\text { side and was not directly visible to } \\
\text { customer. }\end{array}$ & $\begin{array}{l}\text { The menu board was perfectly } \\
\text { displayed and had a clear view } \\
\text { to Customer. }\end{array}$ \\
\hline No samples were given for tasting. & Samples were given for tasting. \\
\hline $\begin{array}{l}\text { There was no special lighting outside } \\
\text { the store }\end{array}$ & Good lighting outside the store. \\
\hline $\begin{array}{l}\text { Fragrance of ice cream was good and } \\
\text { strongly compelling }\end{array}$ & $\begin{array}{l}\text { Fragrance of ice cream was } \\
\text { good and strongly compelling }\end{array}$ \\
\hline $\begin{array}{l}\text { There was no AC inside the store lots } \\
\text { of ventilation through open windows }\end{array}$ & $\begin{array}{l}\text { There was good AC inside the } \\
\text { Store }\end{array}$ \\
\hline
\end{tabular}

\section{b) Comparison of KFC and MacDonald's}

- MacDonald's faired higher on taste when compared to KFC according to the survey done. But sensory marketing strategies and efforts was seen to be higher in KFC when compared to MacDonald's. 50 respondents were questioned.

- Which is better at sensory marketing efforts? The data show in table 5 .

TABLE V. SENSORY MARKETING EFFORTS AT KFC AND MCDONALS

\begin{tabular}{|l|l|}
\hline KFC & 30 \\
\hline McDonalds & 20 \\
\hline
\end{tabular}

- Which sensory organ works great in KFC, show in table 6.

TABLE VI. SENSORY ORGAN WORKS GREAT IN KFC

\begin{tabular}{|l|l|}
\hline Taste & 20 \\
\hline Sight/atmosphere & 3 \\
\hline Smell & 5 \\
Music & 2 \\
\hline Touch & 0 \\
\hline
\end{tabular}

- Which sensory organ works great in McDonalds responds) show in table 7.

TABLE VII. SENSORY ORGAN WORKS GREAT IN MCDONALDS

\begin{tabular}{|l|l|}
\hline Taste & 17 \\
\hline Sight/atmosphere & 3 \\
\hline Smell & 0 \\
Music & 0 \\
\hline Touch & 0 \\
\hline
\end{tabular}

\section{c) Clothes and apparel retailing}

- Comparison of Life style and Pantaloons retail outlets

- Life style and Pantaloons both popular clothing stores were compared for sensory marketing efforts and effectiveness. The survey found that the sensory marketing efforts are best at Pantaloons. Number of people visiting the store was higher and said to have had happier experience shopping here and hence prefers the pantaloons over the other store namely the lifestyle. Table 8 below is the observational comparison conducted for the two stores.

TABLE VIII. COMPARISON LIFESTYLE AND PANTALOONS

\begin{tabular}{|c|c|}
\hline Lifestyle & Pantaloons \\
\hline $\begin{array}{l}\text {-Temperature: Cool } \\
\text {-Lighting: Brightly lit, } \\
\text { symmetrically planned across } \\
\text { the ceiling. } \\
\text {-White flooring enhancing } \\
\text { brightness \& each display } \\
\text { unit was adequately lighted. } \\
\text {-Sound: Music - Slow, soft, } \\
\text { instrumental. } \\
\text {-Interiors- Contemporary and } \\
\text { sleek designs } \\
\text {-Housekeeping: Well-placed } \\
\text { and organized. Racks near the } \\
\text { trial rooms were regularly } \\
\text { emptied. } \\
\text { Promotional strategies to } \\
\text { compliment: } \\
\text { The Inner Circle programme } \\
\text { by paying a fee of Rs.300. } \\
\text { The membership card will be } \\
\text { issued at the time of } \\
\text { enrolment at the store. } \\
\text { exclusive promotions } \\
\text { end of season preview } \\
\text { out of store offers } \\
\text { Birthday Bonus Points } \\
\text { Complimentary shipping } \\
\text { across India } \\
\text { Exclusive gift vouchers. }\end{array}$ & $\begin{array}{l}\text {-Temperature: Comparatively } \\
\text { warmer } \\
\text {-Lighting: Asymmetrical } \\
\text { across ceiling. Highlighted } \\
\text { only the products/racks. } \\
\text {-Light - Yellow, dim lights } \\
\text {-Flooring - Earthy tones. } \\
\text {-Sound: Music- fast, louder } \\
\text { and a combination of popular } \\
\text { English and Hindi songs. } \\
\text {-Interiors - Wooden racks and } \\
\text { earthy tones } \\
\text {-Housekeeping: For certain } \\
\text { brands, the men's and } \\
\text { women's apparels were kept } \\
\text { in the same place which } \\
\text { confused the customers. } \\
\text { Promotional measures: } \\
\text { The Pantaloons Payback } \\
\text { Green card has } 4 \text { tiers } \\
\text { depending on the last } 12 \\
\text { months of shopping. } \\
\text { discounts, } \\
2 \text { Payback Points per INR. } \\
\text { 100/- } \\
\text { complimentary parking } \\
\text { complimentary home drop of } \\
\text { altered garments } \\
\text { relaxed exchange policy } \\
\text { complimentary shipping } \\
\text { exclusive sale preview } \\
\text { exclusive billing counters }\end{array}$ \\
\hline
\end{tabular}

Though Life style scored high on ambience and sensory marketing effort and appeared much more pleasing on observation, it was seen that promotion wise and operational measures, Pantaloons tipped the higher score in the survey conducted. The Overall satisfaction towards Lifestyle and Pantaloons store had customers rooting for Pantaloons over lifestyle.

- Which is better at sensory marketing effort? (50 respondents were questioned). The respondents show in table 9.

TABLE IX. THE RESPONDENTS AT LIFESTYLE AND PANTALOONS

\begin{tabular}{|c|c|}
\hline Lifestyle & 20 \\
\hline Pantaloons & 30 \\
\hline
\end{tabular}

- Which Sensory organ works great in Pantaloons? Table 10 show sensory organ works great in Pantaloons. 
TABLE $X . \quad$ SENSORY ORGAN WORKS GREAT IN PANTALOONS

\begin{tabular}{|l|l|}
\hline $\begin{array}{l}\text { Sight based on } \\
\text { /ambience/ Style }\end{array}$ & 17 \\
\hline Taste & 0 \\
\hline Smell & 4 \\
\hline Music & 4 \\
\hline Touch & 4 \\
\hline
\end{tabular}

\section{FINDINGS}

The paper reports an empirical review by the researcher based on literature available and applying both Quantitative research method and Qualitative research for data collection and analysis to give insights as to how Sensory marketing finds important applications to strategic brand management at the retail level.

The outcome of these research findings will help Retail Marketers understand the following:

- Sensory marketing practices might lead to several different outcomes in several different sectors/majors.

- Help us Understand and predict consumers' buyer behavior and preferences

- Design the right sensory mix (color, shape, taste, smell, texture, and sound) for products, lines and brands.

- Fine-tune their positioning and product range for every local market

- Be more creative in promotion and branding and also systematically increase their innovation hit rate.

\section{A. Sensory Importance Taking Into Account All the Retail Outlets Into Consideration}

In this research, the sensory experience is related to the five human senses, and its impact on the importance in generating customer value, sensory experiences, and the brand as an Figure 3.

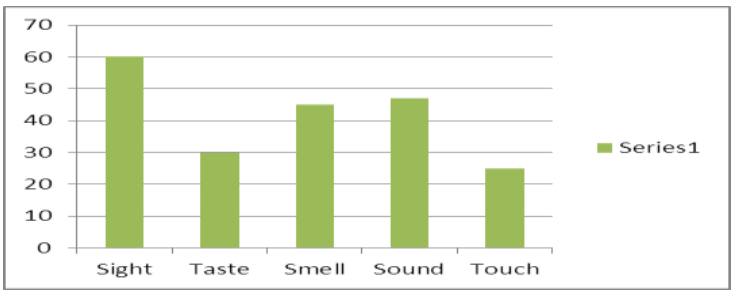

Fig. 3. The sensory experience.

Sight: Sight is easily the most stimulated of five senses sensory marketing to use. Customers can recognize welldesigned logos and color schemes within a matter of seconds. Retail businesses who want to stand out with it today must find a way to go beyond traditional tactics like displays, and do something unique and creative in terms of catching the customer's eye. Visual Merchandising should be taken to a higher and more creative and innovative level $[3,13]$

Sound: To pick the right soundtrack for your sensory marketing tactics, you'll need a deeper understanding of your target audience's sound preference in retail environments, fast- tempo music can cause customers to feel more impatient when waiting in queues [14]. The study revealed people prefer instrumental music.

Smell: The study revealed fragrance is crucial for marketing and branding purposes. Because our sense of smell is tied to our limbic system, it can affect both how we behave, and what we remember about a branded experience [7]. Customer associated freshness and brightness to scents with the store. There were differences in opinion gender wise with regards to smell.

Taste: Food retailers need to focus more on taste followed by visuals imagery to capture the imagination of customers for higher satisfaction levels.

Touch: The study found that customers needed to touch the product to feel the products to buy. This got translated to the brand association and recall, in the customer's memory.

\section{CONCLUSION}

Walt Disney quotes-"People spend money when and where they feel good". Retailers would do well if they took cognizance of this and work around creating a good customer experience every time. This body of study on Sensory Marketing validates how the effect of five human senses contributes to a firm's strategic marketing. The information gathered would facilitate retailing practitioners involved in sensory marketing to become more effective in their businesses and specially help in the visual merchandising strategy. It may be used for a more in-depth scientific academic research in the future. It is quite apparent from the literature review conducted so far, that there still remains tremendous need for research within the domain of sensory marketing considering the advancement in technologies being so rapid, keeping pace with information regarding consumer's changes in tastes and preferences needs to be speeded up, and requires very astute understanding to succeed.

\section{REFERENCES}

[1] By Bertil Hultén, Sensory Marketing, "Theoretical and Empirical Grounds", Publishers Routledge, 2015.

[2] B. Hultén, N. Broweus, M. van Dijk, Marcus van Dijk , Springer, "Sensory Marketing", 21-May-2009 - Business \& Economics

[3] H. Alder, Mind to Mind Marketing: Communicating with 21st-century customers: Kogan Page, 2001

[4] V. Dani and M. Vanishree, "Branding through Sensory Marketing Keywords," Management, vol. 2, no. 11, 2013.

[5] B. Hulten, N. Broweus, and M. Van Dijk, Sinnesmarknadsforing (Malmo. Liber a8.2003), 2003.

[6] P.M. Barwise and Seán, Simply Better: Winning and keeping customers by delivering what matters most: Harvard Business School Press, 2004.

[7] M. Lindstrom, Brand Sense. Sensory secrets behind the stuff we buy. (2nd ed.): Kogan Page, 2010a.

[8] M. Lindstrom, Buyology: Truth and lies about why we buy - Crown Business, 2010b.

[9] M. Lindstrom, Brand washed: Tricks companies use to manipulate ou minds and persuade us to buy: Crown Business, 2011.

[10] E. Babbie, The Practice of Social Research (twelfth ed.): WADSWORTH, CENGACE Learning, 2010.

[11] Khirodhur Latasha, Panyandee Tooraiven, Bappoo Monishan "Analyzing the Impact of Sensory Marketing on Consumers -A Case 
Study of KFC" Proceedings of the International Conference on Tourism, Hospitality and Marketing (IC16Mauritius Conference), 2016.

[12] Natalia Buitrago Hinestroza and Paul TJ James "The effects of sensory marketing on the implementation of fast-food marketing campaigns" Journal of Management and Marketing Research, vol. 14, no. 1, pp. 1 11,2014
[13] Aradhana Krishna, "Customer Sense- How the five senses influence the buying behavior", Kindle edition, 2013.

[14] B. Clegg, Capturing customers' hearts: leave the competition to chase their pockets: Prentice Hall, 2003. 